\title{
A target-controlled infusion regimen for reducing remifentanil-induced coughs
}

\author{
Jong-Yeop Kim, Yun Jeong Chae, Jin-Soo Kim, Yoon-Jeong Park, and Sang-Kee Min \\ Department of Anesthesiology and Pain Medicine, Ajou University School of Medicine, Suwon, Korea
}

Background: This study evaluates the effectiveness of the target-controlled infusion (TCI) of remifentanil through stepwise increases in the effect-site concentration $\left(\mathrm{C}_{\text {eff }}\right)$ in preventing coughs.

Methods: In a preliminary study, we randomly selected 140 patients to receive remifentanil through two-step increases in $\mathrm{C}_{\text {eff }}\left(1.0 \mathrm{ng} / \mathrm{ml}\right.$ to $4.0 \mathrm{ng} / \mathrm{ml}$ : Group $\mathrm{R}_{1-4} ; 2.0 \mathrm{ng} / \mathrm{ml}$ to $4.0 \mathrm{ng} / \mathrm{ml}$ : Group $\left.\mathrm{R}_{2-4}\right)$. Based on the results of the preliminary study, we employed another sample of 140 patients and implemented a three-step increase in TCI (1.0 $\mathrm{ng} / \mathrm{ml}$ to $2.0 \mathrm{ng} / \mathrm{ml}$ to $4.0 \mathrm{ng} / \mathrm{ml}$ : Group $\mathrm{R}_{1-2-4}$ ). We then compared this treatment with direct targeting based on 4.0

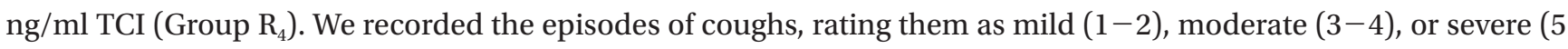
or more).

Results: In Group $\mathrm{R}_{1-4}$, one patient (1.5\%) coughed during the first step, and five (7.3\%) coughed during the second step. In Group $\mathrm{R}_{2-4}$, nine (13.2\%) coughed during the first step, but none coughed during the next step. Only one patient had a mild cough during the three-step increase in TCI, that is, patients in Group $\mathrm{R}_{1-2-4}$ were significantly less likely to cough than those in Group $\mathrm{R}_{4}(\mathrm{P}<0.001)$.

Conclusions: Stepwise increases in the TCI of remifentanil reduced the incidence of remifentanil-induced coughing, and the three-step increase in TCI nearly eliminated remifentanil-induced coughing. (Korean J Anesthesiol 2012; 63: 30-35)

Key Words: Cough, Opioid-related disorders, Remifentanil.

Received: October 5, 2011. Revised: 1st, November 10, 2011; 2nd, December 18, 2011. Accepted: December 20, 2011.

Corresponding author: Sang-Kee Min, M.D., Department of Anesthesiology and Pain Medicine, Ajou University School of Medicine, San 5, Wonchon-dong, Yeongtong-gu, Suwon 443-721, Korea. Tel: 82-31-219-5572, Fax: 82-31-219-5579, E-mail: anesmin@nate.com

(c) This is an open-access article distributed under the terms of the Creative Commons Attribution Non-Commercial License (http:// creativecommons.org/licenses/by-nc/3.0/), which permits unrestricted non-commercial use, distribution, and reproduction in any medium, provided the original work is properly cited. 


\section{Introduction}

Like any other opioid of the fentanyl series, a small dose of intravenous remifentanil often induces coughs during the induction of anesthesia [1-4]. The incidence of remifentanilinduced coughs is known to be between $25 \%$ and $34 \%[5,6]$. The tussive effect of remifentanil is usually transient and selflimited for most patients. However, coughing is unpleasant for patients, and it may be associated with undesirable increases in intracranial, intraocular and intra-abdominal pressure.

Previous studies have demonstrated that various pretreatment methods using drugs such as lidocaine, propofol, ketamine, and dexamethasone can reduce the incidence of remifentanil-induced coughs $[1,6-8]$. However, there is no method that can completely eliminate these coughs. Recent studies have demonstrated the relationship between the occurrence of coughs and the time course of the plasma $\left(\mathrm{C}_{\mathrm{p}}\right)$ and effect-site $\left(\mathrm{C}_{\text {eff }}\right)$ concentrations of remifentanil during the target-controlled infusion (TCI) of remifentanil [6]. In addition, pharmacokinetic (PK) and pharmacodynamic (PD) approaches that maintain the balance between the tussive and antitussive arms of remifentanil are known to be crucial for preventing coughs. Therefore, this study proposes a remifentanil TCI regimen for minimizing remifentanil-induced coughs. The proposed regimen does not require additional pharmacologic preventive measures.

\section{Materials and Methods}

This study was approved by the Institutional Review Board of Ajou University Hospital, Suwon, Korea, and written informed consent was received from every patient. A sample of 280 patients (ASA physical status I or II; 18 to 70 years old) undergoing general anesthesia for gynecologic surgery was employed. In addition, the following criteria were employed to exclude patients from the analysis: body weight exceeding $20 \%$ of the ideal weight, a history of bronchial asthma or chronic obstructive pulmonary disease, respiratory tract infections, or hypertension treated with angiotensin-converting enzyme inhibitors.

No premedication was administered before surgery. A 20-gauge cannula was inserted into the forearm or dorsum of the hand and connected to a three-way stopcock before the patient was transferred to the operating room. Once in the operating room, all patients were monitored through an electrocardiogram, a pulse oximeter, noninvasive blood pressure, and capnography.

The infusion of remifentanil was prepared in a $60 \mathrm{ml}$ syringe (BD $60 \mathrm{ml}$ Syringe, Luer-Lok ${ }^{\mathrm{TM}}$ Tip, BD, USA) with $2 \mathrm{mg}$ of remifentanil diluted with $50 \mathrm{ml}$ of normal saline to make a
$40 \mu \mathrm{g} / \mathrm{ml}$ solution. A TCI pump (Orchestra ${ }^{\circledR}$, Fresenius Vial, Brezins, France) with the pharmacokinetic model in Minto et al. [9] was used for the effect-site targeting of remifentanil. The maximum infusion rate of the syringe pump was set to 1,200 $\mathrm{ml} / \mathrm{hr}$, and the maximum permissible plasma concentration of remifentanil was set to $50 \mathrm{ng} / \mathrm{ml}$. Thus, the overshooting of the plasma concentration was permitted, which avoided interference in maximal delivery by the TCI pump.

In a preliminary study, 140 patients were randomly assigned to one of two groups through computer-generated random numbers. Group $\mathrm{R}_{1-4}$ received remifentanil TCI, which initially targeted $1.0 \mathrm{ng} / \mathrm{ml}$ of $\mathrm{C}_{\text {eff }}$, and Group $\mathrm{R}_{2-4}$ received $2.0 \mathrm{ng} / \mathrm{ml}$ of $\mathrm{C}_{\text {eff }}$. When $\mathrm{C}_{\text {eff }}$ reached each target effect-site concentration $\left(\mathrm{C}_{\mathrm{t}-\mathrm{eff}}\right), \mathrm{C}_{\mathrm{t} \text {-eff }}$ was increased to $4.0 \mathrm{ng} / \mathrm{ml}$. Immediately after the infusion of remifentanil, an observer (blinded to the remifentanil infusion regimens) recorded the occurrence of cough as "yes" or "no" and the onset time of coughs (from the start of the infusion to the first cough). The observer also recorded the duration of coughs (from the start of coughs to their cessation). Coughs were assessed until 1 min after $\mathrm{C}_{\text {eff }}$ reached the final $\mathrm{C}_{\mathrm{t} \text {-eff }}$ of $4.0 \mathrm{ng} / \mathrm{ml}$. During this time, the pseudo steady-state concentration was maintained. Depending on the number of coughs observed, the severity of coughs was rated as none $(0)$, mild $(1-2)$, moderate $(3-5)$, or severe $(>5)$. The amount of remifentanil infused during each step and the total duration to the final target were recorded. The incidence of apnea, the loss of consciousness (LOC), or muscle rigidity was assessed, and assisted mask ventilation with oxygen was applied if desaturation was observed $\left(\mathrm{SpO}_{2}<95 \%\right)$.

TCI simulations with patients were performed using PK/PD software (Asanpump, ver 1.5, Ulsan University, Seoul, Korea). Individual covariates were entered, and the Minto PK/PD model of remifentanil [9] was used. The data refresh interval was set to $2 \mathrm{~s}$. The relationships between the occurrence of coughs and the time course of $\mathrm{C}_{\mathrm{p}}$ and $\mathrm{C}_{\text {eff }}$ of remifentanil were evaluated.

Based on the results of the preliminary study, a regimen was devised in anticipation of the maximum reduction in the incidence of coughs (less than $5 \%$ ). The proposed regimen involved a three-step increase in $\mathrm{C}_{\mathrm{t} \text {-eff }}$ : starting from $1.0 \mathrm{ng} / \mathrm{ml}$ of $\mathrm{C}_{\text {t-eff }}$ and increasing to $2.0 \mathrm{ng} / \mathrm{ml}$ after $30 \mathrm{~s}$ when $\mathrm{C}_{\text {eff }}$ reached the target and finally increasing to $4.0 \mathrm{ng} / \mathrm{ml}$. Another sample of 140 patients was randomly assigned to one of two groups. Group $\mathrm{R}_{1-2-4}$ received remifentanil based on this three-step increase TCI, and Group $\mathrm{R}_{4}$ received a one-step increase in TCI through the direct targeting of $4.0 \mathrm{ng} / \mathrm{ml}$ of $\mathrm{C}_{\text {eff }}$ from the start of the infusion. The evaluation of coughs and TCI simulations were conducted in the manner described earlier.

Considering the incidence of remifentanil-induced coughs to be $25 \%$ [6] and assuming the incidence of coughs to be less 
than $5 \%$ after the application of the proposed regimen, this study required at least 62 subjects per group at the $5 \%$ level of significance and $90 \%$ power of test. The sample size was increased to 70 patients per group to take into account any exclusions. Statistical analyses were conducted using SPSS 13.0 for Windows (SPSS Inc, Chicago, IL, USA). The results are reported as the mean $\pm \mathrm{SD}$ or the number of patients. Continuous data were compared using a two-tailed t-test, and categorical data were analyzed using Fisher's exact test or the chi-square test when appropriate. Here $\mathrm{P}<0.05$ was considered significant.

\section{Results}

Among the 280 patients, 7 did not complete the study because of technical problems such as IV line obstructions, disconnections, and TCI device alarms. There were no differences between groups in terms of their characteristics and smoking status (Table 1). Table 2 shows the infused amounts of remifentanil and the total duration to $4.0 \mathrm{ng} / \mathrm{ml}$ of $\mathrm{C}_{\text {eff }}$ during the remifentanil TCI in the preliminary study. Table 3 shows the incidence, severity, and characteristics of coughs. In Group $\mathrm{R}_{1-4}, 1$ patient (1.5\%) coughed during the first step, and 5 (7.3\%) coughed during the

Table 1. Characteristics of Patients

\begin{tabular}{|c|c|c|c|c|}
\hline & \multicolumn{2}{|c|}{ Preliminary study } & \multirow{2}{*}{$\mathrm{R}_{1-2-4}(\mathrm{n}=67)$} & \multirow{2}{*}{$\mathrm{R}_{4}(\mathrm{n}=70)$} \\
\hline & $\mathrm{R}_{1-4}(\mathrm{n}=68)$ & $\mathrm{R}_{2-4}(\mathrm{n}=68)$ & & \\
\hline Age (yr) & $41.3 \pm 7.6$ & $39.0 \pm 10.6$ & $40.2 \pm 9.8$ & $40.7 \pm 9.9$ \\
\hline Weight (kg) & $59.3 \pm 8.9$ & $58.0 \pm 7.5$ & $58.2 \pm 8.0$ & $60.1 \pm 11.1$ \\
\hline Height (cm) & $160.1 \pm 6.1$ & $160.0 \pm 5.4$ & $159.0 \pm 4.8$ & $160.0 \pm 6.4$ \\
\hline ASA class (I/II) & $55 / 13$ & $52 / 16$ & $54 / 13$ & $57 / 13$ \\
\hline \multicolumn{5}{|l|}{ Smoking history } \\
\hline None & 59 & 55 & 57 & 60 \\
\hline Former & 4 & 6 & 5 & 4 \\
\hline Current & 5 & 7 & 5 & 6 \\
\hline
\end{tabular}

Values represent the mean \pm SD or numbers.

Table 2. Bolus Dose of Remifentanil Targeting the Effect-Site Concentration $\left(\mathrm{C}_{\text {eff }}\right)$

\begin{tabular}{|c|c|c|c|c|}
\hline & \multicolumn{2}{|c|}{ Preliminary study } & \multirow{2}{*}{$\mathrm{R}_{1-2-4}(\mathrm{n}=67)$} & \multirow{2}{*}{$\mathrm{R}_{4}(\mathrm{n}=70)$} \\
\hline & $\mathrm{R}_{1-4}(\mathrm{n}=68)$ & $\mathrm{R}_{2-4}(\mathrm{n}=68)$ & & \\
\hline \multicolumn{5}{|l|}{ Remifentanil at each step $(\mu \mathrm{g} / \mathrm{kg})$} \\
\hline $1^{\text {st }}$ step & $0.26 \pm 0.03$ & $0.52 \pm 0.05$ & $0.26 \pm 0.03$ & $1.03 \pm 0.15$ \\
\hline $2^{\text {nd }}$ step & $0.82 \pm 0.09$ & $0.60 \pm 0.07$ & $0.27 \pm 0.03$ & \\
\hline $3^{\text {rd }}$ step & & & $0.59 \pm 0.09$ & \\
\hline Total $(\mu \mathrm{g} / \mathrm{kg})$ & $1.08 \pm 0.12$ & $1.12 \pm 0.11$ & $1.12 \pm 0.14^{*}$ & $1.03 \pm 0.15$ \\
\hline Time to $4.0 \mathrm{ng} / \mathrm{ml}$ of $\mathrm{C}_{\text {eff }}(\mathrm{min})$ & $2.9 \pm 0.1$ & $2.8 \pm 0.1$ & $3.2 \pm 0.1^{*}$ & $1.5 \pm 0.1$ \\
\hline
\end{tabular}

Values represent the mean $\pm \mathrm{SD}$. $* \mathrm{P}<0.001$ compared with Group $\mathrm{R}_{4}$.

Table 3. Incidence, Severity, and Characteristics of Remifentanil-Induced Coughs

\begin{tabular}{|c|c|c|c|c|}
\hline & \multicolumn{2}{|c|}{ Preliminary study } & \multirow{2}{*}{$\mathrm{R}_{1-2-4}(\mathrm{n}=67)$} & \multirow{2}{*}{$\mathrm{R}_{4}(\mathrm{n}=70)$} \\
\hline & $\mathrm{R}_{1-4}(\mathrm{n}=68)$ & $\mathrm{R}_{2-4}(\mathrm{n}=68)$ & & \\
\hline Total & $6(8.8 \%)$ & $9(13.2 \%)$ & $1(1.5 \%)^{*}$ & $20(28.6 \%)$ \\
\hline Severe & 0 & 0 & 0 & 5 \\
\hline Moderate & 4 & 3 & 0 & 5 \\
\hline Mild & 2 & 6 & 1 & 10 \\
\hline \multicolumn{5}{|l|}{ Cough onset (s) } \\
\hline $1^{\text {st }}$ step & 35.0 & $26.3 \pm 8.1$ & - & $21.6 \pm 8.9$ \\
\hline $2^{\text {nd }}$ step & $21.2 \pm 9.7$ & - & 15.0 & - \\
\hline $3^{\text {rd }}$ step & - & - & - & - \\
\hline Duration (s) & $2.5 \pm 1.5$ & $1.6 \pm 0.7$ & 1.0 & $3.0 \pm 2.1$ \\
\hline Number of coughs & $3.7 \pm 1.8$ & $2.0 \pm 0.9$ & 1.0 & $4.0 \pm 3.1$ \\
\hline
\end{tabular}

Values represent the number of patients (percentage) or the mean \pm SD. "Cough onset" represents the time after the start of each step. $* \mathrm{P}<0.001$ compared with Group $\mathrm{R}_{4}$. 
second step. The mean onset time for coughs for these patients was $111.2 \mathrm{~s}$ after the start of the infusion, but this was also 21.2 $\mathrm{s}$ after the start of the second step. In Group $\mathrm{R}_{2-4}, 9$ (13.2\%) coughed during the first step, but none coughed during the next step. Neither group showed severe coughs. Fig. 1 shows the time courses of $\mathrm{C}_{\mathrm{p}}$ and $\mathrm{C}_{\text {eff }}$ and the occurrence of coughs for Group $\mathrm{R}_{1-4}$ and Group $\mathrm{R}_{2-4}$. For Group $\mathrm{R}_{2-4}$ patients with a cough, $\mathrm{C}_{\mathrm{p}}$ and $\mathrm{C}_{\text {eff }}$ were $4.9 \pm 1.1 \mathrm{ng} / \mathrm{ml}$ and $1.2 \pm 0.4 \mathrm{ng} / \mathrm{ml}$, respectively.

Table 2 shows the infused amounts of remifentanil and the total duration to the final target for Group $\mathrm{R}_{1-2-4}$ and Group $\mathrm{R}_{4}$. The total amount of infused remifentanil and the total duration to $4.0 \mathrm{ng} / \mathrm{ml}$ of $\mathrm{C}_{\text {eff }}$ for Group $\mathrm{R}_{1-2-4}$ far exceeded those for Group $\mathrm{R}_{4}(\mathrm{P}<0.001)$. Table 3 shows the incidence, severity, and characteristics of coughs. Only 1 patient had a mild cough during the three-step increase in TCI, that is, the incidence of coughs was significantly less likely for Group $\mathrm{R}_{1-2-4}$ than for Group $\mathrm{R}_{4}(\mathrm{P}<0.001)$. Fig. 2 shows the time courses of $\mathrm{C}_{\mathrm{p}}$ and $\mathrm{C}_{\text {eff }}$ and the occurrence of coughs for Group $\mathrm{R}_{1-2-4}$ and Group $\mathrm{R}_{4}$. For Group $\mathrm{R}_{4}$ patients with a cough, $\mathrm{C}_{\mathrm{p}}$ and $\mathrm{C}_{\text {eff }}$ were $9.9 \pm 1.7 \mathrm{ng} / \mathrm{ml}$ and $2.3 \pm 0.7 \mathrm{ng} / \mathrm{ml}$, respectively.

In all groups, coughs started between $5 \mathrm{~s}$ and $40 \mathrm{~s}$ after the start of each step. The maximum number of coughs was 12, and 1 patient in Group $\mathrm{R}_{4}$ showed symptoms of opioid-induced muscle rigidity, which was relieved after the administration of propofol and rocuronium. No LOC or apnea was observed during the study.

\section{Discussion}

The results indicate that in the initiation of the intravenous

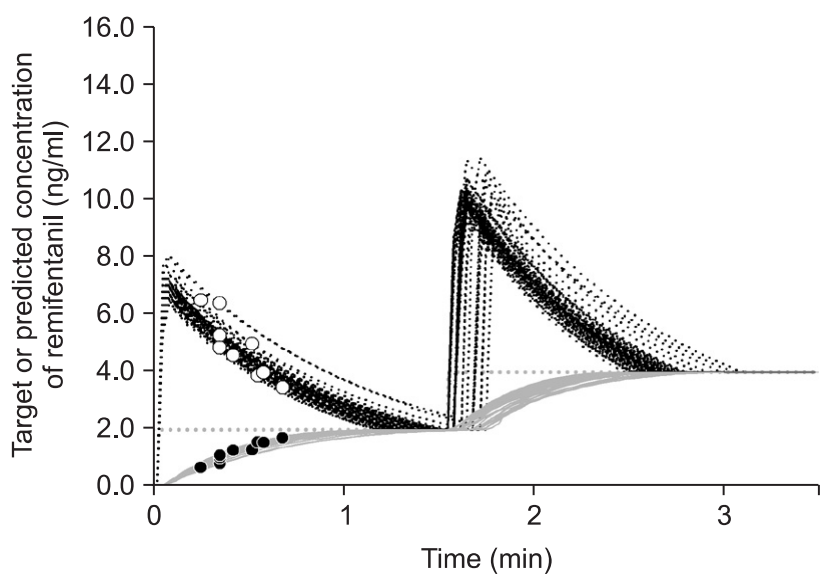

Fig. 1. Time course of the predicted plasma (black dotted line) and the effect-site (gray solid line) concentrations of remifentanil targeting the effect-site concentration (gray dotted line) based on a stepwise increase from $1.0 \mathrm{ng} / \mathrm{ml}$ to $4.0 \mathrm{ng} / \mathrm{ml}$ (left graph) and from $2.0 \mathrm{ng} / \mathrm{ml}$ to $4.0 \mathrm{ng} /$ $\mathrm{ml}$ (right graph). The scattered plot shows the predicted plasma $(\bigcirc)$ and effect-site $(\mathbf{O})$ concentrations for each patient at the onset of coughs.
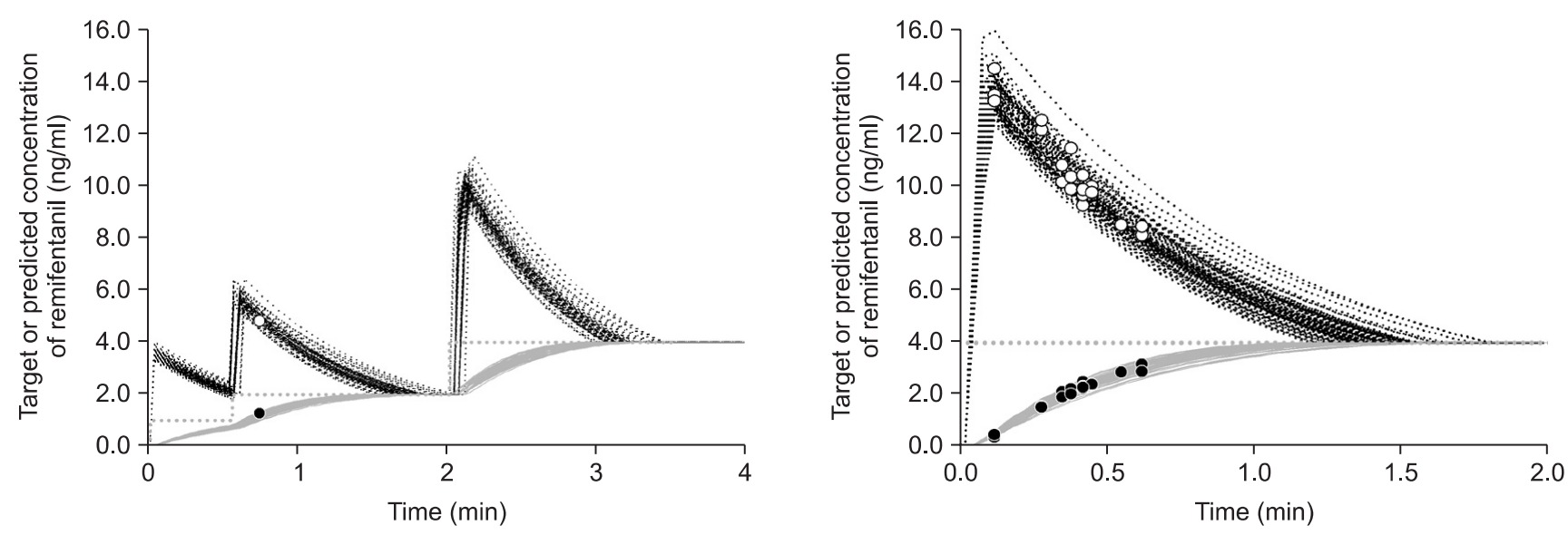

Fig. 2. Time course of the predicted plasma (black dotted line) and the effect-site (gray solid line) concentrations of remifentanil targeting the effect-site concentration (gray dotted line) based on a stepwise increase from $1.0 \mathrm{ng} / \mathrm{ml}$ to $2.0 \mathrm{ng} / \mathrm{ml}$ and to $4.0 \mathrm{ng} / \mathrm{ml}$ (left graph) and a direct increase to $4.0 \mathrm{ng} / \mathrm{ml}$ (right graph). The scattered plot shows the predicted plasma $(\bigcirc)$ and effect-site $(\mathbf{O})$ concentrations for each patient at the onset of coughs. 
infusion of remifentanil targeting $\mathrm{C}_{\text {eff }}$ during the induction of anesthesia, a regimen based on a multi-step increase in $\mathrm{C}_{\text {eff }}$ to the final target of $4.0 \mathrm{ng} / \mathrm{ml}$ of $\mathrm{C}_{\text {eff }}$ is significantly more likely to prevent severe remifentanil-induced coughs and reduce the incidence of coughs than the method based on a direct increase to the final target.

Recently, several studies have employed various methods of opioid injection to prevent opioid-induced coughs [5,10-13]. Some found that the prolongation of the injection time and the slow administration of fentanyl can reduce the incidence of fentanyl-induced coughs [10,11]. A pre-emptive small dose of $25 \mu \mathrm{g}$ of fentanyl, followed by $125 \mu \mathrm{g}$ of fentanyl, has been found to significantly reduce coughs [12]. In another study, Kim et al. [13] found that limiting the peak plasma concentration of remifentanil during TCI can reduce the incidence and severity of coughs. Lim et al. [5] reported that the administration of the graded escalation of $\mathrm{C}_{\text {eff }}$ of remifentanil can suppress coughs, and their methods and findings are generally consistent with those of the present study. However, most of these studies have focused only on reducing the incidence of coughs. Thus, in the present study, we examined the relationship between the provocation and suppression of coughs in the PK/PD contexts.

Combining the preliminary study with previous simulations [6], we summarize the results as follows: First, remifentanilinduced coughs increased in a dose-dependent manner. Second, if $\mathrm{C}_{\mathrm{t}-\mathrm{eff}}$ was increased to $4.0 \mathrm{ng} / \mathrm{ml}$ (bolus of $0.82 \pm 0.09$ $\mu \mathrm{g} / \mathrm{kg}$ ) while $\mathrm{C}_{\text {eff }}$ was maintained at $1.0 \mathrm{ng} / \mathrm{ml}$, then $7.3 \%(5 / 68)$ of patients coughed (second step in $\mathrm{R}_{1-4}$ ), that is, $1.0 \mathrm{ng} / \mathrm{ml}$ of $\mathrm{C}_{\text {eff }}$ was not sufficient for preventing coughs. Third, when there was no remifentanil in the body, in order to increase $C_{t-\text { eff }}$ to 2.0 $\mathrm{ng} / \mathrm{ml}, 0.52 \pm 0.05 \mu \mathrm{g} / \mathrm{kg}$ of remifentanil induced $13.2 \%(9 / 68)$ of patients to cough. However, if only $\mathrm{C}_{\text {eff }}$ was maintained at 2.0 $\mathrm{ng} / \mathrm{ml}$, then no patient coughed even when a similar amount $(0.60 \pm 0.07 \mu \mathrm{g} / \mathrm{kg})$ was administered to increase $C_{\text {t-eff }}$ to $4.0 \mathrm{ng} /$ $\mathrm{ml}$. As a result, we were able to anticipate that with the addition of one additional step (the infusion of the $1 / 3$ increment of $C_{\text {eff }}$ during the second step of $\mathrm{R}_{1-4}$ ), the incidence coughs during the second step decreased by less than $2 \%$ and the overall incidence of coughs decreased by less than $5 \%$, which was proposed as the final endpoint for the incidence of coughs in this study. With this three-step increase in TCI, only one patient coughed, indicating a significant decrease in the incidence of coughs. This regimen may be somewhat cumbersome in routine clinical settings because it requires an appropriate increase in the target. However, all TCI pumps display $\mathrm{C}_{\mathrm{p}}, \mathrm{C}_{\text {eff }}$, and $\mathrm{C}_{\mathrm{t} \text {-eff }}$ on a real-time basis, and some delay in the increase of $\mathrm{C}_{\mathrm{t} \text {-eff }}$ may be beneficial because it offers enough time for reaching the pseudo-steady state of remifentanil.

The simulations using the four infusion regimens considered in this study show the time courses of predicted $\mathrm{C}_{\mathrm{p}}$ and $\mathrm{C}_{\text {eff }}$ of remifentanil during TCI (Fig. 1 and 2). Coughs tended to occur when $\mathrm{C}_{\mathrm{p}}$ was maintained above $\mathrm{C}_{\text {eff }}$, but no coughs were induced when the difference between $\mathrm{C}_{\mathrm{p}}$ and $\mathrm{C}_{\text {eff }}$ decreased or during the steady-steady equilibrium state. Noteworthy is the rapid onset of remifentanil-induced coughs. It took only 5-6 $s$ for three patients of Group $\mathrm{R}_{4}$ to develop a cough. Coughing occurred before the complete injection of the whole bolus dose of remifentanil. During this short interval, it was not likely that remifentanil, injected into the vein of the dorsum of the hand or forearm, reached the central nervous system (CNS). Hoffmann et al. [14] reported that the "arm-to-head time," the interval between the start of the injection of an echo-contrast agent into the antecubital vein and the beginning of signal amplification in the carotid artery, was $14.3 \pm 3.0 \mathrm{~s}$ (min-max 9.0-22.0 s). Blumgart and Weiss [15] detected an active deposit of radium injected into the antecubital vein in the right chamber of the heart at 2.5-14.0 s (arm-to-heart time) and estimated the pulmonary circulation time as $5.5-17.5 \mathrm{~s}$. Therefore, it was not likely that remifentanil entered the CNS within $5 \mathrm{~s}$. Instead, remifentanil might have triggered coughs during pulmonary circulation. These results for cough onset may provide some important clues to the tussive effect via a peripheral acting mechanism. Such a peripheral tussive mechanism offers certain logic to the proposed multi-step regimen. Priming a small bolus dose of remifentanil that is not sufficient for triggering a cough (first steps in $\mathrm{R}_{1-4}$ and $\mathrm{R}_{1-2-4}$ ), while passing the pulmonary circulation, and enters the systemic circulation and the $\mathrm{C}_{\text {eff }}$ could be raised without triggering a cough. In this regard, if only the central antitussive effect at the CNS increases up to a level sufficient for inhibiting a cough in the following administration of remifentanil, then we may prevent coughing. In addition, avoiding a rapid increase in the plasma concentration may reduce the occurrence of coughs.

This study has some limitations. First, we must consider large variations in the remifentanil concentration in the body during the initial period of rapidly mixing immediately after the intravenous injection [16]. In particular, given its onset time, the actual concentrations in the plasma and lung may be substantially different from the predicted concentration. Before its entry into the central circulation, remifentanil may be diluted into the volume, which is different from that of the central compartment. Second, we considered only female patients, and it was difficult to find previous studies comparing the incidence of coughs between male and female patients. However, previous studies of remifentanil-induced coughs $[1,17]$ have reported the incidence of coughs among male and female patients $-26 \%$ and $27.6 \%$, respectively - which are generally consistent with the present study's result (28.6\%). Therefore, there may be little gender difference in the incidence of coughs. Third, we limited 
the target concentrations of remifentanil only to $1.0 \mathrm{ng} / \mathrm{ml}, 2.0$ $\mathrm{ng} / \mathrm{ml}$, and $4.0 \mathrm{ng} / \mathrm{ml}$. In addition, we considered $2.0 \mathrm{ng} / \mathrm{ml}$ of $\mathrm{C}_{\text {eff }}$ as an effective antitussive concentration for the following increase of $\mathrm{C}_{\mathrm{t} \text {-eff }}$ to $4.0 \mathrm{ng} / \mathrm{ml}$. However, this may not hold for higher targets. Therefore, more attention is required when high concentrations of remifentanil are targeted in clinical settings.

In conclusion, based on analyses taking PK/PD approaches, a multi-step increase in the TCI of remifentanil in anticipation of reductions in the incidence of remifentanil-induced coughs may reduce coughing without the need for additional preventive modalities.

\section{References}

1. Kim JY, Park KS, Kim JS, Park SY, Kim JW. The effect of lidocaine on remifentanil-induced cough. Anaesthesia 2008; 63: 495-8.

2. Han JI, Lee GY, Lee CH, Oh EJ. Tussive effect of intravenous fentanyl administration and antitussive effect of lidocaine. Korean J Anesthesiol 1996; 31: 462-5.

3. Pandey CK, Raza M, Ranjan R, Lakra A, Agarwal A, Singh U, et al. Intravenous lidocaine suppresses fentanyl-induced coughing: a double-blind, prospective, randomized placebo-controlled study. Anesth Analg 2004; 99: 1696-8.

4. Yemen TA. Small doses of sufentanil will produce violent coughing in young children. Anesthesiology 1998; 89: 271-2.

5. Lim JH, Ryu SJ, Lim YS. The incidence of cough induced by remifentanil during anesthetic induction was decreased by graded escalation of the remifentanil concentration. Korean J Anesthesiol 2010; 58: 117-21.

6. Kim JY, Lee SY, Kim DH, Park SK, Min SK. Effect-site concentration of propofol for reduction of remifentanil-induced cough. Anaesthesia 2010; 65: 697-703.

7. Kim JY, Kim JY, Park SY, Jung WS, Kwak HJ. Effect of low dose ketamine to prevent remifentanil-induced cough: a randomized, double-blind, placebo controlled trial. Korean J Anesthesiol 2009; 56: 624-7.

8. Yu MS, Kim JY, Kim HY. Intravenous dexamethasone pretreatment reduces remifentanil induced cough. Korean J Anesthesiol 2011; 60: 403-7.

9. Minto CF, Schnider TW, Egan TD, Youngs E, Lemmens HJ, Gambus $\mathrm{PL}$, et al. Influence of age and gender on the pharmacokinetics and pharmacodynamics of remifentanil. I. Model development. Anesthesiology 1997; 86: 10-23.

10. Lin JA, Yeh CC, Lee MS, Wu CT, Lin SL, Wong CS. Prolonged injection time and light smoking decrease the incidence of fentanylinduced cough. Anesth Analg 2005; 101: 670-4.

11. Yu H, Yang XY, Zhang X, Li Q, Zhu T, Wang Y, et al. The effect of dilution and prolonged injection time on fentanyl-induced coughing. Anaesthesia 2007; 62: 919-22.

12. Hung KC, Chen CW, Lin VC, Weng HC, Hsieh SW. The effect of pre-emptive use of minimal dose fentanyl on fentanyl-induced coughing. Anaesthesia 2010; 65: 4-7.

13. Kim JY, Nahm FS, Park YO. Limiting peak plasma concentration effectively decreases remifentanil-induced coughing during targetcontrolled infusion. Anaesth Intensive Care 2008; 36: 746.

14. Hoffmann O, Weih M, Schreiber S, Einhaupl KM, Valdueza JM. Measurement of cerebral circulation time by contrast-enhanced Doppler sonography. Cerebrovasc Dis 2000; 10: 142-6.

15. Blumgart HL, Weiss S. Studies on the velocity of blood flow: VII. The Pulmonary Circulation Time in Normal Resting Individuals. J Clin Invest 1927; 4: 399-425.

16. Egan TD, Minto CF, Hermann DJ, Barr J, Muir KT, Shafer SL. Remifentanil versus alfentanil: comparative pharmacokinetics and pharmacodynamics in healthy adult male volunteers. Anesthesiology 1996; 84: 821-33.

17. Cho HB, Kwak HJ, Park SY, Kim JY. Comparison of the incidence and severity of cough after alfentanil and remifentanil injection. Acta Anaesthesiol Scand 2010; 54: 717-20. 